\title{
Assessment of the Value of Services and Emergy in the Zhoushan Coastal Waters Ecosystem
}

\author{
Chao Liu \\ School of Marine Science and Technology, Zhejiang Ocean University \\ 1 Ocean University S.Rd, Lincheng New District, Zhoushan 316022, Zhejiang, China \\ Tel: 86-152-5708-6939_E-mail: zjoulc@163.com

\begin{abstract}
Wanglai CUI (Corresponding author)
Professor, School of Economics and Management, Zhejiang Ocean University, China E-mail: cwl1018@163.com
\end{abstract}

Haiping YANG (Corresponding author)

Hunan University of Medicine, Hunan Huaihua 418000, China

Tel: 86-189-4205-9562Ｅ-mail: 190756155@qq.com

Xianjiong YU. \& Xiaoli YING

School of Marine Science and Technology, Zhejiang Ocean University, China

Received: Dec. 29, 2016 Accepted: Jan. 11, 2017 Published: May 22, 2017

doi:10.5296/jee.v8i1.10522 URL: https://doi.org/10.5296/jee.v8i1.10522

\begin{abstract}
Based on the four aspects of the marine ecosystem service system, namely supply, regulation, culture and support, the service function system of the marine ecosystem in the Zhoushan coastal area was constructed. The ecosystem valuation by assigning economic value to its services through valuation methods (the market value method, results reference method, shadow engineering method, replacement cost method) and the emergy analysis method were used to estimate the service value of the Zhoushan coastal marine ecosystem. The results
\end{abstract}




\section{Macrothink}

revealed that in 2015, the total valuation of the marine ecosystem services of Zhoushan coastal water was $868.47 \times 10^{4} \mathrm{CNY}$, while the total emergy-currency value was $1246.92 \times 10^{8}$ CNY. The per unit valuation of the ecosystem services was $417.57 \times 10^{4} \mathrm{CNY} / \mathrm{km}^{2}$, while the per unit emergy-currency value is $600 \times 10^{4} \mathrm{CNY} / \mathrm{km}^{2}$. In the total valuation of the Zhoushan offshore ecosystem, the proportion of the values of supply services, regulating services, support services and cultural service was 11.80, 19.47, 29.66 and 39.6\%, respectively. In the total emergy-currency value, the value of the supply services, regulation services and cultural services accounted for $9.19,5.52$ and $85.37 \%$ respectively. The results provide important reference for the maintenance and sustainable use of the marine ecosystem services, scientific management of the marine ecosystem in the Zhoushan coastal waters.

Keywords: Zhoushan coastal waters, Marine ecosystem, Ecosystem services value, Emergy value 


\section{Introduction}

Marine ecosystem services refer to a variety of benefits which the marine ecosystem contributes to human well-being (Chen et al., 2006; Daily et., 1997; Constanza et al., 1997), including four basic types, the supply services, regulatory services, cultural services and support services (Chen et al., 2006; Millennium Ecosystem Assessment, 2005). The assessment of the marine ecosystem services value will estimate the economic value of the service in a currency amount for the particular marine area, which plays a key role in the national economy, compensable use of the marine ecosystem services, ecological compensation, marine or coastal spatial planning, integrated management of the coastal zone and carbon trading (Luisetti et al., 2011).

The specific research on marine ecosystem services has been carried out by the foreign scholars (Constanza et al., 1997; Peterson and Lubchenco, 1997; Holmlund and Hammer, 1999; Duarte Carlos et al., 2000; Souter and Lindén., 2000; Patterson, 2002; Schroter et al., 2005). Marine ecosystem services research in China started relatively late. In 2002, the research on the Jiao Zhou Bay ecosystem services funded by the State Oceanic Administration set a precedent for the study of marine ecosystem services in China. Since then, Chen et al. (2006), Xu et al. (2003) and other scholars tried to establish the framework for the valuation of marine ecosystem services according to the research results of Costanza et al. (1997) and other indicators. In 2005, the State Oceanic Administration launched the research program of the marine ecosystem service function and its value assessment, which mainly focused on the concept of marine ecosystem service, the definition of the content (Chen et al., 2006; Zhang et al., 2007; Shi et al., 2007), the economic attribute (Wang et al., 2006) and service category division (Shi et al., 2007; Zhang et al., 2007; Song et al., 2007). The program achieved a series of empirical research results on natural ecological types, such as sea area (Zhang et al., 2010; Xia et al., 2014; Lai et al., 2013; Qin., 2015), Island (Shi et al., 2009; Wang et al., 2014; Li et al., 2012), Gulf waters (Wang et al., 2010; Xie et al., 2015), mangrove (Han et al., 200) and Coastal Wetlands (Liu et al., 2008; Li et al., 2013). Zhoushan, the key intersection between China's north and south waterway and the Yangtze River golden waterway, is also the main hub of maritime gateway to all over the world and the key foundation for the implementation of the "marine power" stratiogy. In recent years, the Zhoushan marine economy has undergone rapid development and its value to the marine economy increased from $143.8 \times 10^{8} \mathrm{CNY}$ in 2004 to $766 \times 10^{8} \mathrm{CNY}$ in 2015 . Hence, the marine economy has become the main growth sector of the Zhoushan economic development. However, with further ocean exploration, the marine ecosystem in Zhoushan has been facing a series of problems, such as the disorder of the sea development, the serious pollution of the coastal area and the serious decline of the fishery resources. Accordingly, this study will research on the Zhoushan coastal waters, analyze and evaluate the Zhoushan offshore marine ecosystem services and its economic value. The data collected will contribute to the understanding of the marine ecosystem services by humans, the establishment of the scientific ocean values concept and sustainable development idea, the conscious adjustment of the development and utilization of the marine ecosystem, the supply of ecological economic theoretical support for the sustainable utilization and management decision of the 
Zhoushan marine ecosystem services and the provision of reference for the amount of exploitation and marine pollution accident compensation.

As the marine ecosystem is open, the ecosystem service value is estimated to quantify the various components of the system of ecological value. Accordingly, when estimating the value of the ecosystem services in use, we only consider the main flow of energy in the marine ecosystem and its relationship to renewable energy systems, which are not included in the study during the estimation process. The method of emergy evaluation and economic valuation in the dynamic process of the marine ecosystem is shown in Figure 1.

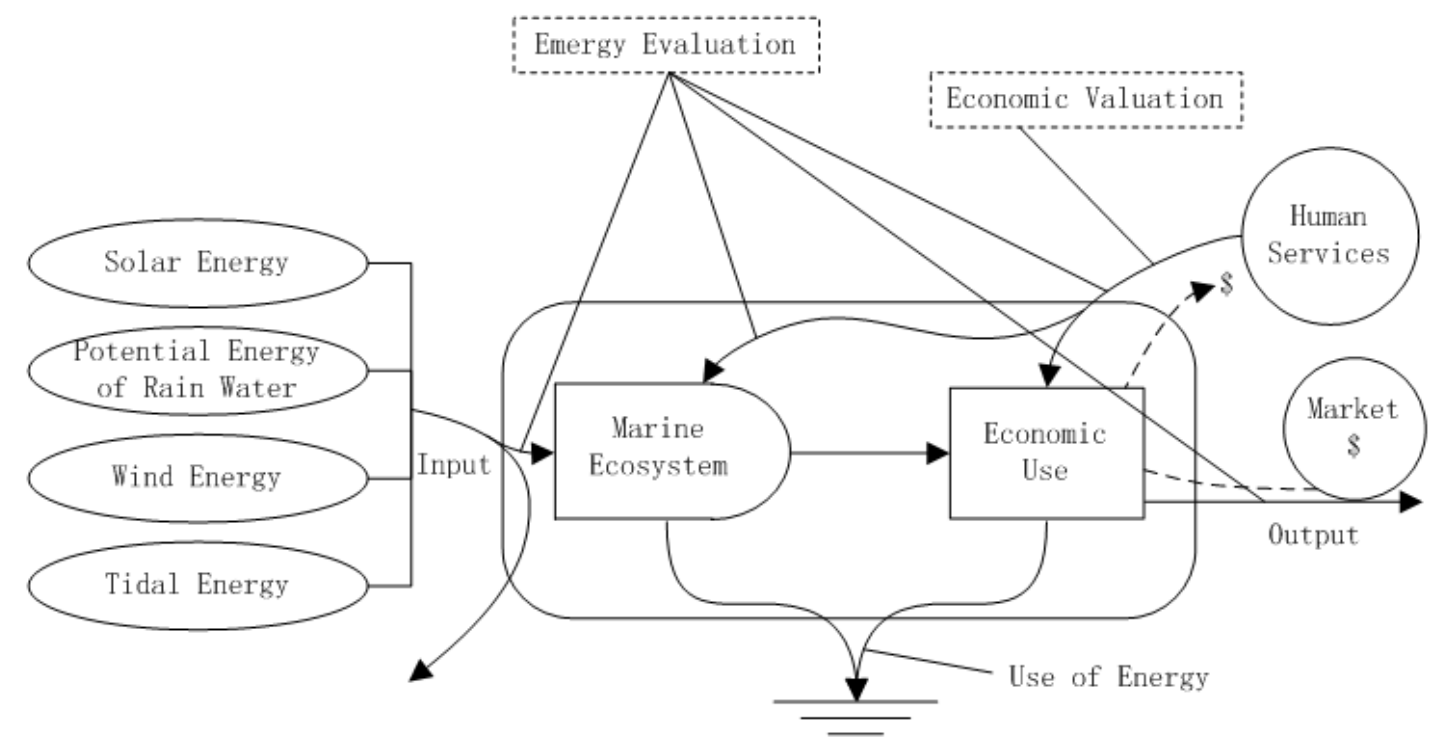

Figure 1. Emergy and economic valuation of the inshore marine ecosystem services in Zhoushan

\section{Materials and Methods}

\subsection{Overview of the Area Where the Research is Conducted and Data Sources}

Zhoushan city is located on the southeast coast of China, surrounded by the East China Sea on the east, Hangzhou Bay on the west, Zhejiang Province on the South and close to the Yangtze River Estuary on the north. It has a subtropical monsoon climate. The coastline is extends for $2444 \mathrm{~km}$, accounting for $7.6 \%$ of the total sea area of China, and the sea area of Zhoushan is up to $2.08 \times 10^{4} \mathrm{~km}^{2}$, which is 14.4 times of its land area. The sea area of Zhoushan is dotted with numerous islands, equivalent to about $20 \%$ of the total number of islands in China. There are more than 58 islands whose size are over $1 \mathrm{~km}^{2}$, accounting for $96.9 \%$ of the total area of the islands. Zhoushan sea water depth is generally from $20 \mathrm{~m}$ to 40 $\mathrm{m}$, the main deep water sections are $38 \mathrm{~m}$. The sea line over $15 \mathrm{~m}$ deep is up to $200.7 \mathrm{~km}$, while that over $20 \mathrm{~m}$ deep is about $103.7 \mathrm{~km}$. In the summer the Zhoushan sea surface average temperature is around 28 to $29^{\circ} \mathrm{C}$, while in the winter it is $8^{\circ} \mathrm{C}$. The average salinity of the Zhoushan sea is 29 to $34 \%$ monthly. There are 1163 species of marine organisms identified in the Zhoushan coastal zone and coastal waters, including 91 species of phytoplankton, 103 species of zooplankton, 480 species of benthic animals, 131 species of 


\section{Macrothink}

benthic plants and 358 species of swimming animals. The large yellow croaker, small yellow croaker, octopus and cuttlefish (Squid) are the 4 most abundant type of sea animals, the main varieties of fish include more than 36 kinds such as eel, chub mackerel, grouper, horse crab, shrimp, etc. Zhoushan city has the typical characteristics of a city by the sea, such as fishing, island, harbor, sea lines, business and those tourism resources combined with island scenery. Marine culture and Buddhist culture are unique in the Yangtze River Delta cities.
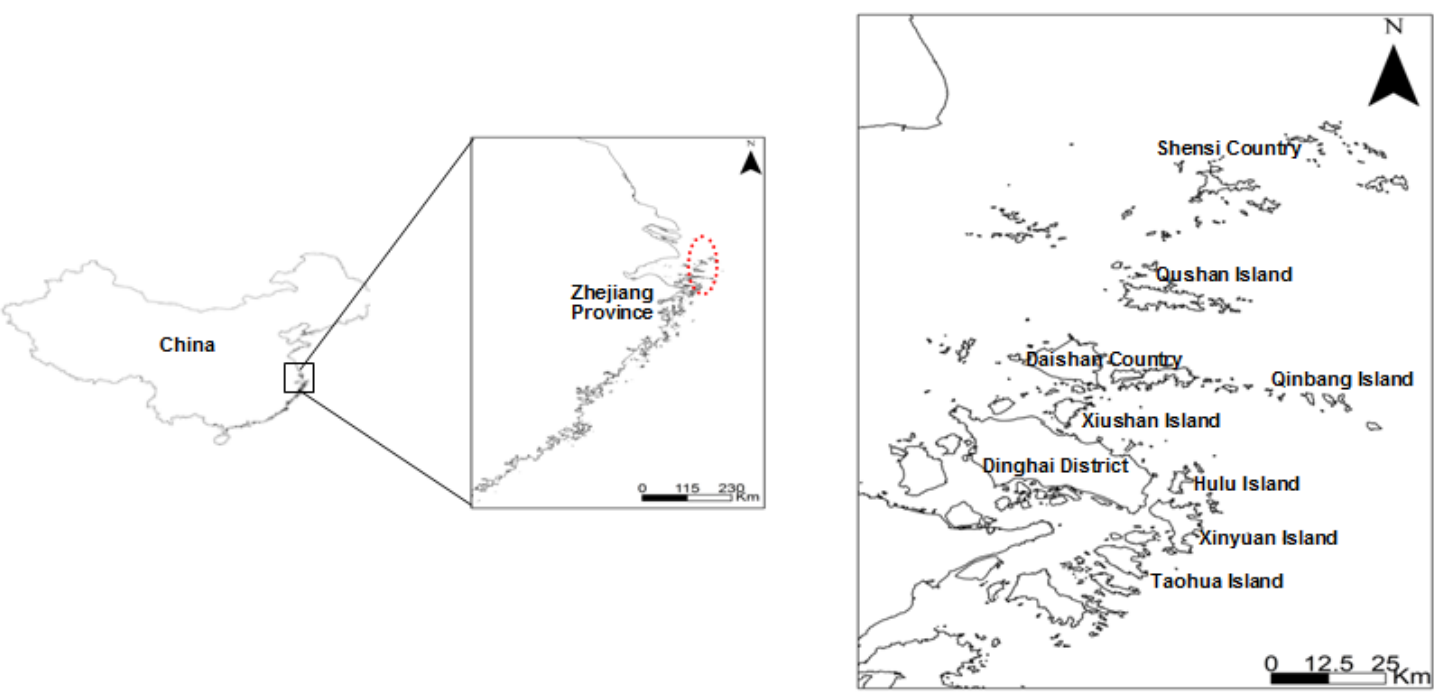

Figure 2. Schematic representation of the study area

\subsection{Research methods}

\section{Food supply}

Food supply refers to the sea food services provided to humans by the marine ecosystem. The food supply service in the Zhoushan Ocean consists of two parts, namely the Zhoushan inshore seafood products and aquaculture production of seafood including fish, shrimps, crabs, shellfish, seaweed and other edible seafood. When using the market value method to calculate the value of the food supply, it is required to deduct the cost of production. The formula used to calculate it are based on the monetary value method (Market Value Method):

$$
V_{f}=\sum_{i=1}^{n} Q F_{i} \times M F_{i}-\sum_{i=1}^{n} R F_{i}
$$

and the emergy evaluation method:

$$
V_{f_{E}}=\sum_{i=1}^{n} \frac{Q F_{i} \times T_{S_{i}}}{E_{m r}}
$$

Where, $V_{f}$ refers to food supply service value $(\mathrm{CNY} / \mathrm{a}) ; Q F_{i}$ denotes the amount of category seafood in Zhoushan inshore fishing (t/a); $M F_{i}$ indicates the category seafood 
market price $(\mathrm{CNY} / \mathrm{t}) ; R F_{i}$ refers to the category seafood cost $(\mathrm{CNY} / \mathrm{t}) . V_{f_{E}}$ is the

emergy-currency value of food production service (CNY/a); $T_{S}$ represents to emergy conversion ratio of the category seafood (seJ/unit); Emr is the emergy dollar ratio (seJ/\$).

\section{Gene resource supply}

Gene resources refers to the genes and genetic information carried by marine organisms, which are directly related to the number of marine species in the proper region (Zhang et al., 2007). The genetic resources supply service of the marine ecosystem in the Zhoushan coastal waters are mainly derived from the effectiveness of the marine gene resources utilization as well as the potential benefit of the gene resources development. The formula used for its calculation are based on the monetary value method (Results Reference Method):

$$
V_{n}=Q_{n} \times P
$$

and the emergy evaluation method:

$$
V_{n_{E}}=\frac{Q_{d} \times T_{d}}{E_{m r}}
$$

Where, $V_{n}$ is the Value of the gene resources supply (CNY/a); $Q_{n}$ refers to the value of the gene resources supply in the unit area of the Zhoushan sea area $\mathrm{CNY} /\left(\mathrm{km}^{2} \cdot \mathrm{a}\right) ; P$ denotes the Zhoushan sea area $\left(\mathrm{km}^{2}\right) ; V_{n_{E}}$ represents the emergy-currency value of maintaining the diversity of the Zhoushan sea area (CNY/a); $Q_{d}$ indicates the number of species in the sea area; $T_{d}$ denotes the emergy conversion ratio of the species (seJ/unit); Emr is the emergy dollar ratio $(\mathrm{seJ} / \$)$.

\section{Climate regulating}

Climate regulating services is used to explain the absorption of greenhouse gases by marine ecosystems and various ecological processes, such as the role of the marine biological pump which will achieve the regional or global climate regulation (Zhang et al., 2007). Marine ecosystem climate regulating services in the Zhoushan area come from marine organisms (such as algae, shellfish, etc.), which will absorb and fix various greenhouse gas by photosynthesis. A previous study showed that the contribution of $\mathrm{CO}_{2}$ in the climate regulating services is high to $70 \%$ (Melillo et al., 1990). Thus, the regulation of the $\mathrm{CO}_{2}$ content in the atmosphere needs to be considered when evaluating the climate regulating services of the marine ecosystem. The formula used to calculate it are based on the monetary value method (Market Value Method):

$$
V_{c}=Q_{c} \times P_{c}
$$


and the emergy evaluation method:

$$
V_{c_{E}}=\frac{Q_{C} \times T_{C}}{E_{m r}}
$$

Where, $V_{c}$ is the value of climate regulation services (CNY/a); $Q_{c}$ denotes the fixed volume of $\mathrm{CO}_{2}(\mathrm{t} / \mathrm{a}) ; P_{C}$ is the market transaction price of $\mathrm{CO}_{2}(\mathrm{CNY} / \mathrm{a}) ; V_{C_{E}}$ represents the emergy-currency value of the climate regulation services $(\mathrm{CNY} / \mathrm{a}) ; T_{C}$ is emergy conversion ratio of $\mathrm{CO}_{2}$ (seJ/unit); Emr is the emergy dollar ratio (seJ/\$).

\section{Air quality control}

Air quality control services mainly refer to the stable amount of $\mathrm{CO}_{2}$ absorption by the marine ecosystem and the maintenance of the atmospheric chemical composition by primary oxygen producers through photosynthesis (Zhang et al., 2007). The air quality control service of the Zhoushan marine ecosystem is mainly derived from the release of oxygen by marine organisms. The formula used to calculate it are based on the monetary value method (Shadow Engineering Method):

$$
V_{o}=Q_{O} \times P_{O}
$$

and the emergy evaluation method:

$$
V_{O_{E}}=\frac{Q_{O} \times T_{O}}{E_{m r}}
$$

Where, $V_{O}$ is the value of the air quality control (CNY/a); $Q_{O}$ refers to the quantity of oxygen released from the offshore waters of Zhoushan (t/a); $P_{O}$ refers to each unit cost of oxygen $(\mathrm{CNY} / \mathrm{t}) ; V_{O_{E}}$ represents the emergy-currency value of the air quality control service $(\mathrm{CNY} / \mathrm{a}) ; Q_{O}$ denotes the amount of oxygen generatiod from the study area; $T_{O}$ is the oxygen emergy conversion ratio (seJ/unit); Emr denotes the emergy dollar ratio (seJ/\$).

\section{Water purification and regulation}

Water purification and regulation mainly refers to decomposition reduction, transfer and transformation, absorption and degradation, as well as removal of all kinds of harmful substances in the marine ecosystem due to the involvement of a variety of ecological processes in the marine ecosystem (Zhang et al., 2007). Water purification and regulation services of the Zhoushan marine ecosystem mainly manifests through the biological 


\section{Macrothink}

purification of $\mathrm{N}$ (nitrogen) and $\mathrm{P}$ (phosphorus) in the coastal waters, as well as the removal of COD (Chemical Oxygen Demand) and petroleum hydrocarbons. The formula used for its calculation are based on the monetary value method (Shadow Engineering Method):

$$
V_{w}=\sum_{i=1}^{n} Q W_{i} \times C W_{i}
$$

and the emergy evaluation method:

$$
V_{w_{E}}=\sum_{i=1}^{n} \frac{Q_{w_{i}} \times T_{w_{i}}}{E_{m r}}
$$

Where, $V_{w}$ refers to the Service value of the water quality purification and regulation in the Zhoushan sea area (CNY/a); $Q W_{i}$ refers to the pollutants quantity in the category I purified in the Zhoushan sea area (t/a);CW $i$ is the unit cost for the pollutants of category I purified in the Zhoushan sea area $(\mathrm{CNY} / \mathrm{t}) . V_{w_{E}}$ is the emergy-currency value of the water quality purification and regulation service in the Zhoushan sea area $(\mathrm{CNY} / \mathrm{a}) ; T_{w_{i}}$ is the emergy conversion ratio of the pollutants of category I (seJ/unit); Emr is the emergy dollar ratio $(\mathrm{seJ} / \$)$.

\section{Biological control}

Biological control mainly refers to the biological regulation and control of the pests and diseases in the marine ecosystem (Zhang et al., 2007). The Zhoushan coastal waters of the biological control services mainly refers to the regulation and suppression of harmful biological activities (such as the incidence of red tide reduction, etc.). The formula used to calculate it are based on the monetary value method (Results Reference Method):

$$
V_{h}=D_{h} \times P
$$

and the emergy evaluation method:

$$
V_{h_{E}}=\frac{D_{h e \times T_{h}}}{E_{m r}}
$$

Where, $V_{h}$ refers to the supply service value of the biological control (CNY/a); $D_{h}$ denotes each unit value of the biological control services in the Zhoushan area $\mathrm{CNY} /\left(\mathrm{km}^{2} \cdot \mathrm{a}\right) ; P$ is the Zhoushan sea area $\left(\mathrm{km}^{2}\right) . V_{h_{E}}$ is the emergy-currency value of the 
biological control service (CNY/a); $D_{h e}$ is the potential seafood resources in a particular sea area; $T_{h}$ refers to the emergy conversion ratio of the seafood resources (seJ/unit); Emr is the emergy dollar ratio (seJ/\$).

\section{Interference regulating}

The interference regulating service is defined as the inclusion, attenuation and integratiod function of the marine ecosystem to various environmental fluctuations (such as the reduction of the number of typhoon, storm surge, etc.) (Zhang et al., 2007). The interference regulating service of the Zhoushan ocean ecosystem mainly denotes the attenuation effect that the marine marsh grass community and beach have on natural adversities, such as the ocean storm tide. The formula used to calculate it is based on the monetary value method (Results Reference Method):

$$
V_{S}=D_{S} \times P
$$

Where, $V_{S}$ denotes the supply service value of gene resources (CNY/a); $D_{S}$ is each unit of interference regulating service value provided by the marine organisms in the Zhoushan sea area $\mathrm{CNY} /\left(\mathrm{km}^{2} \cdot \mathrm{a}\right) ; \quad P$ denotes the Zhoushan sea area domain $\left(\mathrm{km}^{2}\right)$.

\section{Support function}

Support service refers to the basic services required for the production of other ecosystem services, including the maintenance of its species composition, quantity stability, the supply biological carrier use for material circulation and emergy flow in the system and the support provided to other services ( $\mathrm{Li}$ and Tan, 2013). The support function of the Zhoushan sea area ecosystem is mainly derived from the nutrient circulation, material cycle, biodiversity, habitat, etc. The formula used for its calculation is based on the monetary value method (Results Reference Method):

$$
V_{m}=\left(D_{m}+K_{m}\right) \times P
$$

Where, $V_{m}$ is the value of the support function service (CNY/a); $D_{m}$ is the unit value of the nutrient recycling service provided by marine organisms $\mathrm{CNY} /\left(\mathrm{km}^{2} \cdot \mathrm{a}\right) ; K_{m}$ is the unit value of the habitat provided by marine organisms $\mathrm{CNY} /\left(\mathrm{km}^{2} \cdot \mathrm{a}\right) ; P$ is the Zhoushan sea area domain $\left(\mathrm{km}^{2}\right)$.

\section{Education and scientific research}

Education and scientific research service refers to the contribution of the human knowledge system made by the scientific research because of the complexity and diversity of the marine ecosystem, the growth of the national economy and improvement of human welfare (Zhang et 
al., 2007). The education and scientific research services of the Zhoushan marine ecosystem are mainly derived from the investment in marine scientific research, as well as the number of marine scientific research achievements. The used for its estimation are based on the monetary value method (Cost Substitution Method):

$$
V_{k}=\frac{\sum S I_{n}}{N} \text { or } V_{k}=V S \times P
$$

and the emergy evaluation method:

$$
V_{k_{E}}=\frac{S I \times T_{i}}{E_{m r}}
$$

Where, $V_{k}$ refers to the value of education and scientific research service (CNY/a); $S I_{n}$ is the scientific research investment within $\mathrm{N}$ years (CNY/ article); $\mathrm{N}$ denotes the number of years; VS is the benchmark price of the shallow cultural research $\mathrm{CNY} /\left(\mathrm{km}^{2} \cdot \mathrm{a}\right) ; \mathrm{P}$ denotes the Zhoushan sea area domain $\left(\mathrm{km}^{2}\right) . V_{k_{E}}$ is the emergy-currency of the educational research service (CNY/a); SI is the number of essay related to the sea area (each ); $T_{i}$ is the emergy conversion ratio of the essay (seJ/unit); Emr refers to the emergy dollar ratio (seJ/\$).

\section{Tourism and entertainment}

Tourism and entertainment service refers to the unique landscape and aesthetic features formed by the coastal and marine ecosystems, and the direct commercial value that has been generatiod, such as marine ecological tourism, fishing tours and fishing activities (Zhang et al., 2007). Along the coast of Zhoushan, there are abundant natural resources and landscape, such as natural beach, island and natural coastal wetlands, which are of great value for coastal leisure tourism. The value of tourism and entertainment services of the Zhoushan coastal marine ecosystem is evaluated directly by the value of the coastal tourism industry (monetary value method). The formula for calculating the energy value is based on the energy value method:

$$
V_{b_{E}}=\frac{D_{b} \times T_{b}}{E_{m r}}
$$

Where, $V_{b_{E}}$ refers to the emergy-currency value of the tourism and entertainment service $(\mathrm{CNY} / \mathrm{a}) ; D_{b}$ denotes the income from coastal tourism (CNY); $T_{b}$ is the emergy conversion ratio of the coastal tourism income (seJ/\$); Emr is the emergy dollar ratio (seJ/\$).

\section{Result and analysis}

\section{Food supply}


According to the 2015 national economic and social development statistics bulletin of Zhoushan city and the 2015 fishing village income distribution annual analysis of Zhoushan city, in 2015 the Zhoushan marine fishing and aquaculture production was $176.46 \times 10^{4} \mathrm{t}$ in total, while the total output value of marine fishery was up to $137.12 \times 10^{8} \mathrm{CNY}$ (the average price was $7879 \mathrm{CNY} / \mathrm{t}$ ). The ocean fishing production was $46.52 \times 10^{4} \mathrm{t}$; the mariculture area was $5779 \mathrm{hm}^{2}$, thus the yield was $14.17 \times 10^{4} \mathrm{t}$. Meanwhile, the processing capacity of aquatic products was $73.26 \times 10^{4} \mathrm{t}$, while the output value of aquatic products was $264.39 \times 10^{8} \mathrm{CNY}$ (profit ratio of aquatic products processing was $20 \%$ estimates, including fishing). Based on the market value method, from the total output value of marine fishery we deducted the deep-sea fishing cost, the cost for the processing of seafood (about $80 \%$ of the aquatic product processing output value), the offshore marine fishery production cost, then added the processing cost of seafood products. According to formula (1-1), in 2015 the food supply service price of the marine ecosystem in the coastal waters of Zhoushan was $92.91 \times 10^{8} \mathrm{CNY}$.

The seafood emergy conversion ratio is $3.35 \times 10^{6} \mathrm{seJ} / \mathrm{J}$ (Campbell et al., 2005). According to formula (2-1), the food supply services emergy of the Zhoushan coastal marine ecosystem is $2.18 \times 10^{21} \mathrm{seJ} / \mathrm{a}$, and the emergy-currency value is $11.73 \times 10^{8} \mathrm{CNY}$.

\section{Gene resource supply}

De Groot suggested that each unit gene resources value of an ecosystem is (6-112) $\$ /\left(\mathrm{hm}^{2} \cdot \mathrm{a}\right)$ (Wu et al., 2008). Located in a subtropical marine ecological system, the Zhoushan sea water has a superior natural environment and abundant attractions. Accordingly, the muddy sea water creates favorable conditions for different habitats for migratory fish to migratio, reproduce and grow, which then form the famous fishing ground - the Zhoushan fishing ground with high genetic resources value. Thus, we take $60 \%$ of the highest value of De Groot as the unit gene resources service value of the Zhoushan sea ecosystem, namely 436.8 $\mathrm{CNY} /\left(\mathrm{hm}^{2} \cdot \mathrm{a}\right)(\mathrm{RMB}$ exchange ratio 1:6.5\$, the same below). According to formula (1-2), we calculated that in 2015 the gene resources service value of the Zhoushan coastal marine ecosystem was $9.08 \times 10^{8} \mathrm{CNY}$.

There are 1163 marine species completely identified in the coastal zone of Zhoushan and coastal waters, according to Zhoushan sea marine organism history. The marine emergy conversion ratio is $1.64 \times 10^{19} \mathrm{seJ} / \mathrm{each}$. According to formula (2-2) we calculated the food supply service emergy of the Zhoushan marine ecosystem is $1.91 \times 10^{22} \mathrm{seJ} / \mathrm{a}$, while the emergy-currency value is $1.03 \times 10^{10} \mathrm{CNY}$ (Zhao et al., 2015).

\section{Climate regulation}

Based on the primary productivity research, the average annual primary productivity in the Zhoushan sea is greater than $400 \mathrm{~g} /\left(\mathrm{m}^{2} \cdot \mathrm{a}\right)$ (Li et al., 2005). Accordingly, we take $400 \mathrm{~g} /\left(\mathrm{m}^{2} \cdot \mathrm{a}\right)$ as the minimum conservative value of the primary productivity of the Zhoushan sea, which will be calculated by the average value of $617.95 \mathrm{CNY} / \mathrm{t}$ of the cost of afforestation (with $260.90 \mathrm{CNY} / \mathrm{t}$ ) and carbon tax (the Swedish carbon tax is $0.15 \$ / \mathrm{kg}$ ). The solid carbon of the Zhoushan sea area is $832 \times 10^{4} \mathrm{t}$. According to formula (1-3) we calculated that in 2015 the 
climate regulation service value provided by the Zhoushan marine ecosystem was $51.41 \times 10^{8}$ CNY.

As it is established, the $\mathrm{CO}_{2}$ emergy conversion ratio is $8.85 \times 10^{7} \mathrm{seJ} / \mathrm{g}$ (Buenfil, 2001). According to formula (2-3) we calculated the climate regulation service emergy of the Zhoushan marine ecology system is $7.37 \times 10^{20} \mathrm{seJ} / \mathrm{a}$, and the emergy-currency value is $3.96 \times 10^{8} \mathrm{CNY}$.

\section{Air quality control}

Based on the Zhoushan ocean primary productivity, the value is calculated by the average value $330.45 \mathrm{CNY} / \mathrm{t}$ of the cost of afforestation (valued as $260.9 \mathrm{CNY} / \mathrm{t}$ ) and the cost of the industrial oxygen production (normally $400 \mathrm{CNY} / \mathrm{t}$ ). According to formula, the release of $\mathrm{O}_{2}$ $=2.667 \times \mathrm{QPP}($ phytoplankton primary productivity $) \times \mathrm{P}($ Zhoushan area $)$, we calculated that the Zhoushan waters annual release of $\mathrm{O}_{2}$ is $2218.94 \times 10^{4} \mathrm{t}$. In addition, according to formula (1-4), we calculated the air quality control service value of the Zhoushan marine ecosystem as $73.32 \times 10^{8} \mathrm{CNY}$ annually.

As we know that the $\mathrm{O}_{2}$ emergy conversion ratio is $8.65 \times 10^{7} \mathrm{seJ} / \mathrm{g}$ (Buenfil, 2001), we calculated the air quality control service emergy of the Zhoushan coastal marine ecosystem as $5.26 \times 10^{20}$ seJ/a according to formula (2-4), while the emergy value is $2.83 \times 10^{8} \mathrm{CNY}$ (Zhao et al., 2015).

\section{Interference regulating}

The research results of Costanza et al. (2007) showed that each unit interference regulating the service value of the coastal waters is $88 \$ /\left(\mathrm{hm}^{2} \cdot \mathrm{a}\right)$, or $572 \mathrm{CNY} /\left(\mathrm{hm}^{2} \cdot \mathrm{a}\right)$. Thus, according to formula (1-5) we calculated the annual interference regulating service value of the Zhoushan coastal marine ecosystem as $11.90 \times 10^{8} \mathrm{CNY}$.

\section{Water purification and regulating}

The ratio of planktonic algae using $\mathrm{C}$ (carbon), $\mathrm{N}$ and $\mathrm{P}$ is 106: 16: 1 , which is relatively fixed and called the Redfield value. When phytoplankton fix each $1 \mathrm{~mol}$ of $\mathrm{C}$, they will absorb $16 \mathrm{~mol}$ of $\mathrm{N}$ and $1 \mathrm{~mol}$ of $\mathrm{P}$ at the same time. According to the primary productivity of the Zhoushan sea area and the quantity of $\mathrm{N}$ and $\mathrm{P}$ absorbed by phytoplankton, we estimated an annual quantity of $\mathrm{N}$ and $\mathrm{P}$ fixed by the Zhoushan marine ecosystem as $70.44 \mathrm{~g} /\left(\mathrm{m}^{2} \cdot \mathrm{a}\right)$ and $9.75 \mathrm{~g} /\left(\mathrm{m}^{2} \cdot \mathrm{a}\right)$, respectively. Using the previously reported cost of domestic sewage treatment for $\mathrm{N}(1500 \mathrm{CNY} / \mathrm{t})$, and P (2500 CNY/t) (Zhao et al., 2003) and the formula (1-6) we calculated the $\mathrm{N}$ and $\mathrm{P}$ biological purification value of the Zhoushan offshore marine ecosystem as $27.05 \times 10^{8}$.

According to the "management measures for sewage charges" formulated by the State Council, we calculated the value of COD and petroleum hydrocarbons removal with the cost of COD removal at $4300 \mathrm{CNY} / \mathrm{t}$ and the cost of oil removal $7000 \mathrm{CNY} / \mathrm{t}$ (Zhang et al., 2010). Using the pollution control cost method and the reference of the COD and the petroleum hydrocarbon environmental capacity of the coastal waters in Zhejiang Province (Li et al., 2013), we estimated the value of the COD and petroleum hydrocarbons in the Zhoushan 
coastal waters (Table 1). According to the "2015 annual Zhoushan Marine Environment Bulletin", in 2015 on March, May, August and October, the average proportion of the first-class, second-class, third-class and fourth-class water area were 1.4, 6.8, 14 and 29\%. Thus, we estimated that the annual removal value of the Zhoushan marine ecosystem of petroleum hydrocarbon COD value is $0.72 \times 10^{8} \mathrm{CNY}$. Accordingly, the annual value of the water purification and regulating service provided by the Zhoushan marine ecosystem in Zhoushan is $27.77 \times 10^{8} \mathrm{CNY}$.

Table 1. The value of the COD and petroleum hydrocarbons removal in the Zhoushan coastal sea

\begin{tabular}{lcccc}
\hline $\begin{array}{c}\text { Water quality } \\
\text { standard }\end{array}$ & $\begin{array}{c}\text { COD } \\
\text { environment } \\
\text { capacity } \\
\left(10^{4} /(\mathrm{t} \cdot \mathrm{a})\right)\end{array}$ & $\begin{array}{c}\text { COD removal value } \\
\left(10^{8} /(\mathrm{CNY} \cdot \mathrm{a})\right)\end{array}$ & $\begin{array}{c}\text { Petroleum } \\
\text { hydrocarbons } \\
\text { capacity } \\
\left(10^{4} /(\mathrm{t} \cdot \mathrm{a})\right)\end{array}$ & $\begin{array}{c}\text { The removal value of } \\
\text { petroleum } \\
\text { hydrocarbons } \\
\left(10^{8} /(\mathrm{CNY} \cdot \mathrm{a})\right)\end{array}$ \\
\hline First class & 2.48 & 1.07 & 0.19 & 0.13 \\
Second class & 3.72 & 1.80 & 0.19 & 0.13 \\
Third class & 4.96 & 2.13 & 1.14 & 0.80 \\
Forth class & 6.20 & 2.67 & 1.91 & 1.34 \\
\hline
\end{tabular}

As it is established, the N, P emergy conversion ratio are $1.51 \times 10^{9} \mathrm{seJ} / \mathrm{g}$ and $1.36 \times 10^{10} \mathrm{seJ} / \mathrm{g}$ (Odum et al., 2000). According to formula (2-5) we calculated the service emergy of $\mathrm{N}$ absorbed by Zhoushan marine ecosystem as $2.22 \times 10^{21} \mathrm{seJ} / \mathrm{a}$, with a emergy-currency value of $11.95 \times 10^{8} \mathrm{CNY}$, and the service emergy of $\mathrm{P}$ as $1.81 \times 10^{21} \mathrm{seJ} / \mathrm{a}$, with a emergy-currency value of $9.74 \times 10^{8} \mathrm{CNY}$.

\section{Biological control}

The research results obtained by Costanza et al. (2007) showed that each unit biological control service value of the coastal waters is $38 \$ /\left(\mathrm{hm}^{2} \cdot \mathrm{a}\right)$. Additionally, De Groot reported that each unit biological control service value of the ecosystem is $(2-78) \$ /\left(\mathrm{hm}^{2} \cdot \mathrm{a}\right)(\mathrm{Wu}$ et al., 2008). Taking the average of each, $39 \$ /\left(\mathrm{hm}^{2} \cdot \mathrm{a}\right)$, namely $253.5 \mathrm{CNY} /\left(\mathrm{hm}^{2} \cdot \mathrm{a}\right)$, as each unit of biological control service value of the Zhoushan ecosystem, we calculated the annual biological control service value provided by the Zhoushan ecosystem as $5.27 \times 10^{8} \mathrm{CNY}$, using the formula (1-7).

According to the research results, the maximum sustainable fishery resource in the Zhoushan sea area was $48.6678 \times 10^{4} \mathrm{t} / \mathrm{a}(\mathrm{Ni}$ and $\mathrm{Lu}, 2002)$, and the conversion ratio of the marine products was $3.35 \times 10^{6} \mathrm{seJ} / \mathrm{J}(\mathrm{Campbell}$ et al., 2005). According to formula (2-6), the emergy of the biological control service provided by the marine ecosystem in the Zhoushan coastal area is $7.51 \times 10^{21} \mathrm{seJ} / \mathrm{a}$, with a emergy-currency value of $4.04 \times 10^{9} \mathrm{CNY}$ (Zhao et al., 2015).

\section{Habitat}

In view of the availability of data, this study only estimated the value of the services provided by the habitat. According to the research results, the marine habitat value is $8 \$ /\left(\mathrm{hm}^{2} \cdot \mathrm{a}\right)$, namely $52 \mathrm{CNY} /\left(\mathrm{hm}^{2} \cdot \mathrm{a}\right)$ (Constanza et al., 1997). According to formula (1-8), the annual value of the nutrient circulation service provided by the Zhoushan marine ecosystem is $1.08 \times 10^{8} \mathrm{CNY}$. 


\section{Nutrient circulation}

Costanza et al. (2007) suggested that the public sea area of nutrient circulation is 118 $\$ /\left(\mathrm{hm}^{2} \cdot \mathrm{a}\right)$, coastal nutrient circulation is $3677 \$ /\left(\mathrm{hm}^{2} \cdot \mathrm{a}\right)$. Taking the average of both, 1897.50 $\$ /\left(\mathrm{hm}^{2} \cdot \mathrm{a}\right)$, or $12333.75 \mathrm{CNY} /\left(\mathrm{hm}^{2} \cdot \mathrm{a}\right)$. According to formula $(1-8)$, the annual value of the nutrient circulation service provided by the Zhoushan marine ecosystem is $256.54 \times 10^{8} \mathrm{CNY}$.

\section{Education and scientific research}

The research results reported by Costanza et al. (1997) showed that each unit area of cultural service value of coastal waters is $62 \$ /\left(\mathrm{hm}^{2} \cdot \mathrm{a}\right)$, or $403 \mathrm{CNY} /\left(\mathrm{hm}^{2} \cdot \mathrm{a}\right)$. Chen and Zhang (2000) estimated that each unit of scientific research and cultural service value of various ecosystems in China is $3.55 \times 10^{4} \mathrm{CNY} /\left(\mathrm{km}^{2} \cdot \mathrm{a}\right)$. Taking the average of both, $3.79 \times 10^{4}$ $\mathrm{CNY} /\left(\mathrm{km}^{2} \cdot \mathrm{a}\right)$ as each unit of scientific research and cultural service value of the Zhoushan sea area, using formula (1-9) we calculated the annual education and scientific research value of the Zhoushan marine ecosystem as $7.88 \times 10^{8} \mathrm{CNY}$.

Based on Melillo et al. (1990), we conducted a network query, from 2006 to 2015, of databases, such as CNKI, Wanfang database, VIP database and Web Science, Science Direct, and found that there are a total of 5257 articles with the topic of the Zhoushan sea, which represents an annual average of 525.7 articles. Using the emergy-currency value of these scientific articles to assess the service emergy value of education and scientific research, the emergy conversion ratio of the articles is $1.17 \times 10^{18} \mathrm{seJ} /$ article. Thus, according to formula (2-7), we calculated the emergy of the education and scientific research service in the Zhoushan marine ecosystem as $6.15 \times 10^{20} \mathrm{seJ} / \mathrm{a}$, while the emergy-currency value is $3.31 \times 10^{8}$ CNY.

\section{Travelling and entertainment}

In 2015, Zhoushan received a total of $3876.22 \times 10^{4}$ visitors, including $32.24 \times 10^{4}$ international tourists, $3843.98 \times 10^{4}$ domestic tourists, and the total tourism revenue was $552.18 \times 10^{8} \mathrm{CNY}$. Considering that the tourism and entertainment services of the marine ecosystem mainly took place in coastal and offshore waters, if we assume that $60 \%$ of Zhoushan tourism revenue was the value resulting from leisure and entertainment service function, the tourism entertainment service value produced by the Zhoushan marine ecosystem in 2015 was $331.31 \times 10^{8} \mathrm{CNY}$.

Based on the results of the present study, considering that the tourism income emergy conversion ratio is $4.94 \times 10^{12} \mathrm{seJ} / \$$ (Zhao, 2005). According to formula (2-8), we calculated the emergy of the Zhoushan marine ecological tourism and entertainment services as $1.64 \times 10^{23} \mathrm{seJ} / \mathrm{a}$, while the emergy-currency value is of $10.60 \times 10^{10} \mathrm{CNY}$.

\section{Statistical analysis of marine ecosystem service value in Zhoushan coastal waters}

The results presented in Table 2 and Table 3 reveal that the total value of the coastal marine ecosystem in Zhoushan city in 2015 was $868.47 \times 10^{8} \mathrm{CNY}$, the gross domestic product (GDP) was $1095 \times 10^{8} \mathrm{CNY}$, the marine ecosystem service value accounted for $79.31 \%$ of the GDP, $113.38 \%$ of the total output value of the marine economy, while the value of the marine 
ecosystem in the unit areawas $417.57 \times 10^{4} \mathrm{CNY} / \mathrm{km}^{2}$. The supply services, regulating service, support service and cultural services accounted for 11.80, 19.47, 29.66 and 39.06\% of the total value of the marine ecosystem, which indicates that the cultural service function has the largest valuation in the Zhoushan marine ecosystem, followed by the support function, regulating services and supply service. In the classification of sub function, the service function value of the Zhoushan coastal marine ecosystem in descending order are: tourism and entertainment, nutrient circulation, food supply, air quality regulation, climate regulation, water purification regulation, disturbance regulation, gene resource supply, educational research services and biological control.

In 2015 , the emergy of the Zhoushan coastal marine ecosystem was $19.8 \times 10^{22}$ seJ, the total emergy-currency value was $1246.92 \times 10^{8} \mathrm{CNY}$, the ecosystem service emergy-currency value of per unit area was $600 \times 10^{4} \mathrm{CNY} / \mathrm{km}^{2}$. The supply of services, regulating services, cultural services value accounted for 9.19, 5.52 and $85.37 \%$. In the valuation of the Zhoushan coastal marine ecosystem, tourism and entertainment services accounted for the largest proportion, which means that in the development of a marine industry economy, the marine tourism industry is still an important part of the development of the marine ecosystem in Zhoushan, and is a key part to promote the development of marine economy in Zhoushan city.

Table 2. Service value of the Zhoushan marine ecosystem in 2015

\begin{tabular}{|c|c|c|c|c|}
\hline Service type & Sub-function & $\begin{array}{l}\text { Service value } \\
\quad(\mathrm{CNY} / \mathrm{a})\end{array}$ & $\begin{array}{l}\text { Value per unit area } \\
\mathrm{CNY} /\left(\mathrm{km}^{2} \cdot \mathrm{a}\right)\end{array}$ & $\begin{array}{c}\text { Ratio of } \\
\text { value } \\
(\%)\end{array}$ \\
\hline \multirow{2}{*}{$\begin{array}{l}\text { Supply } \\
\text { service }\end{array}$} & Food supply & $92.91 \times 10^{8}$ & $44.67 \times 10^{4}$ & 10.75 \\
\hline & Gene resource supply & $9.08 \times 10^{8}$ & $4.37 \times 10^{4}$ & 1.05 \\
\hline \multirow{5}{*}{$\begin{array}{l}\text { Regulating } \\
\text { service }\end{array}$} & Climate regulating & $51.41 \times 10^{8}$ & $24.72 \times 10^{4}$ & 5.92 \\
\hline & Air quality control & $73.32 \times 10^{8}$ & $35.25 \times 10^{4}$ & 8.44 \\
\hline & Disturbance regulating & $11.90 \times 10^{8}$ & $5.72 \times 10^{4}$ & 1.37 \\
\hline & Water purification regulating & $27.77 \times 10^{8}$ & $13.38 \times 10^{4}$ & 3.20 \\
\hline & Biological control & $5.27 \times 10^{8}$ & $2.53 \times 10^{4}$ & 0.54 \\
\hline \multirow{2}{*}{$\begin{array}{l}\text { Supporting } \\
\text { service }\end{array}$} & Habitat & $1.08 \times 10^{8}$ & $0.52 \times 10^{4}$ & 0.12 \\
\hline & Nutrient circulation & $256.54 \times 10^{8}$ & $123.34 \times 10^{4}$ & 29.54 \\
\hline \multirow{2}{*}{$\begin{array}{l}\text { Cultural } \\
\text { service }\end{array}$} & Educational research & $7.88 \times 10^{8}$ & $3.79 \times 10^{4}$ & 0.91 \\
\hline & Tourism and entertainment & $331.31 \times 10^{8}$ & $159.28 \times 10^{4}$ & 38.15 \\
\hline Totally & & $868.47 \times 10^{8}$ & $417.57 \times 10^{4}$ & 100 \\
\hline
\end{tabular}

Table 3. Value of inshore marine ecosystem service emergy value in Zhoushan

\begin{tabular}{|c|c|c|c|c|c|c|c|}
\hline $\begin{array}{l}\text { Service } \\
\text { type }\end{array}$ & Sub-function & Raw data & $\begin{array}{l}\text { Emergy } \\
\text { tansformity } \\
\text { (seJ/unit) }\end{array}$ & $\begin{array}{l}\text { Emergy } \\
(\mathrm{seJ} / \mathrm{a})\end{array}$ & $\begin{array}{c}\text { Emergy-currency } \\
\text { value }(\mathrm{CNY} / \mathrm{a})\end{array}$ & $\begin{array}{l}\text { Emergy-currency value } \\
\text { per unit area } \\
\mathrm{CNY} /\left(\mathrm{km}^{2} \cdot \mathrm{a}\right)\end{array}$ & $\begin{array}{l}\text { Ratio } \\
\text { of } \\
\text { value } \\
(\%)\end{array}$ \\
\hline \multirow[b]{2}{*}{$\begin{array}{l}\text { Supply } \\
\text { service }\end{array}$} & Food supply & $6.52 \times 10^{14} \mathrm{~J}$ & $3.35 \times 10^{6}$ & $2.18 \times 10^{21}$ & $11.73 \times 10^{8}$ & $5.64 \times 10^{4}$ & 0.94 \\
\hline & $\begin{array}{l}\text { Gene resource } \\
\text { supply }\end{array}$ & $\begin{array}{l}1163 \\
\text { pieces }\end{array}$ & $1.64 \times 10^{19}$ & $1.91 \times 10^{22}$ & $1.03 \times 10^{10}$ & $49.5 \times 10^{4}$ & 8.25 \\
\hline \multirow{5}{*}{$\begin{array}{l}\text { Regulating } \\
\text { service }\end{array}$} & $\begin{array}{l}\text { Climate } \\
\text { regulating }\end{array}$ & $8.32 \times 10^{12} \mathrm{~g}$ & $8.85 \times 10^{7}$ & $7.37 \times 10^{20}$ & $3.96 \times 10^{8}$ & $1.90 \times 10^{4}$ & 0.32 \\
\hline & $\begin{array}{l}\text { Air quality } \\
\text { control }\end{array}$ & $6.07 \times 10^{12} \mathrm{~g}$ & $8.65 \times 10^{7}$ & $5.26 \times 10^{20}$ & $2.83 \times 10^{8}$ & $1.36 \times 10^{4}$ & 0.23 \\
\hline & nitrogen uptake & $1.47 \times 10^{12} \mathrm{~g}$ & $1.51 \times 10^{9}$ & $2.22 \times 10^{21}$ & $11.95 \times 10^{8}$ & $5.74 \times 10^{4}$ & 0.96 \\
\hline & $\begin{array}{l}\text { Phosphorus } \\
\text { uptake }\end{array}$ & $2.03 \times 10^{11} \mathrm{~g}$ & $1.36 \times 10^{10}$ & $1.81 \times 10^{21}$ & $9.74 \times 10^{8}$ & $4.69 \times 10^{4}$ & 0.78 \\
\hline & $\begin{array}{l}\text { Biological } \\
\text { control }\end{array}$ & $2.2410^{15} \mathrm{~J}$ & $3.35 \times 10^{6}$ & $7.51 \times 10^{21}$ & $4.04 \times 10^{9}$ & $19.4 \times 10^{4}$ & 3.23 \\
\hline
\end{tabular}




\begin{tabular}{l|l|l|l|l|l|l|l}
\hline \multirow{2}{*}{$\begin{array}{l}\text { Cultural } \\
\text { services }\end{array}$} & $\begin{array}{l}\text { Educational } \\
\text { research } \\
\text { services }\end{array}$ & $\begin{array}{l}525.7 \\
\text { articles }\end{array}$ & $1.17 \times 10^{18}$ & $6.15 \times 10^{20}$ & $3.31 \times 10^{8}$ & $1.59 \times 10^{4}$ & 0.27 \\
\cline { 2 - 8 } & $\begin{array}{l}\text { Tourismand } \\
\text { entertainment }\end{array}$ & $\begin{array}{l}3.31 \times 10^{10} \\
\text { CNY }\end{array}$ & $2.96 \times 10^{12}$ & $1.64 \times 10^{23}$ & $10.60 \times 10^{10}$ & $5.10 \times 10^{6}$ & 85.10 \\
\hline Totally & & & & $19.8 \times 10^{22}$ & $1246.92 \times 10^{8}$ & $600 \times 10^{4}$ & 100 \\
\hline
\end{tabular}

Note: The emergy dollar ratio is $2080 \times 10^{13} \mathrm{seJ} / \$$.

\section{Conclusion and prospect}

The huge service function value of the Zhoushan offshore marine ecosystem provides great value to the economic development of Zhoushan city. Accordingly, the health and stability of the Zhoushan ocean economy play a significant role in the development of the national economy. The evaluation results show that the function of marine education and scientific research service in Zhoushan is worth to be implemented. Moreover, the investment in the field of marine research needs to be increased in order to improve the research ability, which is combined with basic research, applied research, data research. Due to the limitations of the human understanding and research on the sea, the research on the service type of the marine ecosystem still needs to be further developed. The service functions proposed and evaluated in our study is much less than the actual marine functions, and in the evaluation process, because of certain obstacles, such as the evaluation method, average value of evaluation data errors, we assumed the research value to be lower than the value provided by the actual marine ecosystem value. Therefore, the value of the marine ecosystem in Zhoushan coastal waters reported here is only a conservative estimation.

\section{References}

Buenfil, A. A. (2001). Emergy evaluation of water. Dissertation for Ph.D degree. Gainesville: University of Florida, USA

Campbell, D. E., Brandt-Williams, S. L., \& Meisch, M. E. A. (2005). Environmental Accounting Using Emergy: Evaluation of the State of West Virginia. EPA/600 /R-02/011. USEPA, Office of Research and Development,Washington, D.C. pp.116.

Chen, S., Zhang, Z. H., Ma, Y., Shi, H. H., Ma, A. Q., Zheng, W., Wang, Q. X., Peng, Y. L., \& Liu, J. (2006). Program for service evaluation of marine ecosystems in China waters.

Advances in Earth Science, 21(11), 1127-1133.

http://dx.chinadoi.cn/10.3321/j.issn:1001-8166.2006.11.004

Chen, Z. X., \& Zhang, X. S. (2000). Valuation of China's ecological system. Chinese Science Bulletin, 1, 17-22. http://dx.chinadoi.cn/10.3321/j.issn:0023-074X.2000.01.004.

Constanza, R. D'., Arge, R., \& Groot, R. (1997). The value of the world's ecosystem services and nature capital. Nature. 387(15), 253-260.

Daily, G. C. (1997). Nature's services: societal dependence on natural ecosystems. Natures Services Societal Dependence on Natural Ecosystems, 1(00), 220-221. 
Duarte, C. M. (2000). Marine biodiversity and ecosystem services: An elusive link . Journal of Experimental Marine Biology and Ecology, 250(1-2), 117-131.

http://dx.doi.org/10.1016/S0022-0981(00)00194-5.

Han, W. D., Gao, X. M., LU, C. Y., \& Lin, W. D. (2000). The ecological values of mangrove ecosystems in China. Ecologic Science, 19(1), 40-46.

http://dx.chinadoi.cn/10.3969/j.issn.1008-8873.2000.01.007.

Holmlund, C. M., \& Hammer, M. (1999). Ecosystem services generatiod by fish populations. Ecological Economics, 29(2), 253-268.

Holmlund, C. M., \& Hammer, M., (2004). Effects of fish stocking on ecosystem services: an overview and case study using the Stockholm archipelago. Environmental Management, 33(6), 799-820. http://dx.doi.org/10.1007/s00267-004-0051-8.

Jiang, M. M., Zhou, J. B., Chen, B., \& Chen, G. Q. (2008). Emergy based ecological account for Chinese economy in 2004. Communications in Nonlinear Science and Numerical Simulation, 13(10), 2337-2356.

Lai, J. X., Jiang, F. J., Xu, M. B., Chen, M., Li, Y. C., \& Chen, B. (2013). Value assessment of offshore marine ecosystem service. Journal of Guangxi Academy of Sciences, 29(4), 252-258. http://dx.chinadoi.cn/10.3969/j.issn.1002-7378.2013.04.07.

Li, G. S., Wang, F., Ling, Q., \& Li, J. L. (2005). Estimation of ocean primary productivity by remote sensing and introduction to spatio-temporal variation mechanism for the East China Sea. Acta Geographica Sinica, 58(4), 483-493. http://dx.chinadoi.cn/10.11821/xb200304001.

Li, H. X., \& Tan, C. L. (2013). Assessment of marine ecosystem value and services in Zhejiang province. Jiangsu Agricultural Sciences, 41(4), 307-310.

http://dx.chinadoi.cn/10.3969/j.issn.1002-1302.2013.04.118.

Li, L. F., Hui, S. R., Song, H. L., \& Su, F. L. (2013). Evaluation of the services provided by the Shuangtai estuary wetland in Panjin based on emergy theory. China Environmental Science, 33(8), 1454-1458. http://dx.chinadoi.cn/1000-6923.2013.08. 05.

Li, Z. Y., Xu, S. J., Xu, H. Y., \& Cai, X. (2012). Value assessment of offshore marine ecosystem service in Leizhou Peninsula. Journal of South China Normal, 44(4), 133-137. http://dx.chinadoi.cn/10.6054/j.jscnun.2012.09.027.

Liu, J., Chen, S., Xia, T., \& Wang, Q. X. (2008). Analysis on changes of Wetland Landscape in Yellow River Delta and influences on ecosystem services. Advances in Marine Science, 26(4), 464-470. http://dx.chinadoi.cn/10.3969/j.issn.1671-6647.2008.04.007.

Luisetti, T., Turner, R. K., Bateman, I. J., Morse-Jones, S., Adams, C., \& Fonseca, L. (2011). Coastal and marine ecosystem services valuation for policy and management: Managed realignment case studies in England. Ocean \& Coastal Management, 54(3), 212-224. http://dx.doi.org/10.1016/j.ocecoaman.2010.11.003 
MA(Millennium Ecosystem Assessment). (2005). Ecosystems and Human Well-being: A Framework for Assessment. Washington: Island Press. pp.5-76.

Melillo. J. M., Callaghan, T. V., \& Woodward, F. I. (1990). Effects on ecosystems// Houghton, J. T., Jenkins, G. J., Ephraums, J. J., eds. Climate change: the IPCC scientific assessment. Cambridge University Press. pp.283-310.

Odum, H. T. (1996). Evnironmental accounting: Emergy and environmental decision making .New York:Wilely. pp.15-163

Patterson, M. G. (2002). Ecological production based pricing of biosphere processes. Ecological Economics, 41(3), 457-478.

Peterson, C. H., Lubchenco, J., \& Daily, G. C. (1997). Marine ecosystem services. Natures Services Societal Dependence on Natural Ecosystems, 38, 135-170.

Qin, C. X., Chen, P. M., Zhang, A. K., Yuan, H. D., Li, G. Y,. Shu, L. M., Zhou, Y. B., \& Li, X. G. (2015). Evaluation of ecosystem service and emergy of Wanshan Waters in Zhuhai, Guangdong Province, China. Chinese Journal of Applied Ecology, 26(6), 1847-1853.

Schroter, D., Cramer, W., Leemans, R., Prentice, I. C., Araujo, M.,Arnell, N., Bondeau, A., Bugmann, H., Carter, T., Gracia, C., Vega-Leiner, A. C. D., Erhard, M., Ewert, F., Glendining, M., House J., Kankaanpaa, S., Klein, R. J. T., Lavorel, S., Lindner, M., Metzger, M., Meyer, J., Mitchell, T., Reginster, I., Rounsevell, M., Sabate, S., Sitch, S., Smith, B., \& Smith, J. (2005). Ecosystem service supply and vulnerability to global change in Europe. Science, 310, 1333-1337. http://dx.doi.org/ 10.1126/science.1115233.

Shi, H. H., Zhen, W., Ding, D. W., \& Lv, J. B. (2008). Valuation of typical marine ecosytem services-A case study in Sanggou Bay. Marine Environmental Science, 27(2), 101-104. http://dx.chinadoi.cn/10.3969/j.issn.1007-6336.2009.06.035.

Shi, H. H., Zhen. W., \& Chen, S. (2007). Study on marine ecosystem service and its Value Assessment. Ecological Economy, 3, 139-141. http://dx.chinadoi.cn/10.3969/j.issn.1671-4407.2007.03.033

Shi, H. H., Zheng, W., Ding, D. W., \& Lv, J. B. (2008).Valuation of typical marine ecosytem services-A case study in Sanggou Bay. Marine Environmental Science, 27(2), 101-104.

Song, R., Zhen, H. B., \& Zhang, S. S. (2007). Study on marine ecosystem service function and value evaluation. Environmental Protection and Circular Economy, 6, 47-50.

Souter, D. W., \& Lindén, O. (2000). The health and future of coral reef systems. Ocean \& Coastal Management, 43(8-9), 657-688. http://dx.doi.org/10.1016/S0964-5691(00)00053-3.

Wang, H., \& Wang, J. Y. (2006). Study on the economic attribute of marine ecosystem service. Coastal Engineering, 25(4), 77-82.

Wang, L., Chen, S., Ren, D. C., Ke, S. Y., Li, J. M., \& Wang, D. (2010). Valuation of Species Diversity Maintenance Service in Luoyuan Bay Based on Contingent Valuation Method. Advances in Earth Science, 25(8), 886-892. 
Wu, S. S., Liu, R. Z., Qi, L. M., \& Liang, X. B. (2008). Value assessment of marine ecosystem service in Bohai Sea. China Population, Resources and Environment, 18(2), 65-69. http://dx.chinadoi.cn/10.3969/j.issn.1002-2104.2008.02.013.

Xia, T., Chen, S., Zhang, T., \& Wang, M. (2014). Valuation of ecosystem services in Jiangsu coastal waters. Acta Ecologica Sinica, 34(17), 5069-5076.

http://dx.chinadoi.cn/10.3969/j.issn.1000-3037.2011.02. 11.

Xie, X. F., Wu, T., Jiang, G. J., Zhang, H. Q., \& Zhang, Y. (2015). Value assessment of marine ecosystem services in Yueqing Bay. Journal of Applied Oceanography, 34(4), 496-500. http://dx.chinadoi.cn/10.3969 /J.ISSN.2095-4972.2015.04.006.

Xu, C. C., \& Han, Z. L. (2003). Framework for valuation of marine ecosystem services. Ecological Economy, 10, 199-202.

Zhang, H., Kang, X., Wang, L., \& Fu, J. (2010). Assessment of offshore marine ecosystem value and services in Liaoning province. Resources Science, 32(1), 177-183. http://dx.chinadoi.cn/10.3969/j.issn.1007-7588.2010.01.07.

Zhang, Z. H., Lu, J. B., \& Ding, D. W. (2007). Classification and measurement of marine ecosystem services. Coastal Engineering, 26(1), 57-63.

Zhang, Z. H., Shi, H. H., Jiang, Z. B., Chen S., \& Ding, D.W. (2006). Sources and implementation of marine ecosystem services. Chinese Journal of Ecology, 25(12), 1574-1579. http://dx.chinadoi.cn/10.3321/j.issn:1000-4890.2006.12.026.

Zhang, Z. H., Zhou, J., L, J. B., \& Ding, D. W. (2007). Connotation and characteristics of marine ecosystem services. Marine Environmental Science, 26(3), 259-263.

http://dx.chinadoi.cn/10.3969/j.issn.1007-6336.2007.03.014.

Zhao, S., Li, M. N., \& Wu, C. W. (2015). Emergy valuation of ecosystem services in the Zhoushan marine area. Acta Ecologica Sinic., 35(3), 678-685. http://dx.chinadoi.cn/10.5846 /stxb201304080629.

Zhao, S., Zhang, H. S, Zhang, L. P., \& Chen, W. Q. (2007). Emergy value of mangrove ecosystem services in China. Resources Science, 29(1), 147-154.

http://dx.chinadoi.cn/10.3321/j.issn:1007-7588.2007.01.022.

Zhao, T. Q., Ouyang, Z. Y., Wang, X. K., Miao, H., \& Wei, Y. C. (2003). Ecosystem services and their valuation of terrestrial surface water system in China. Journal of Natural Resouces, 18(4), 443-452. http://dx.chinadoi.cn/10.11849/zrzyxb.2003.04.008.

Zhao, X. F. (2005). Quantitative analysis of emergy synthesis for Zhongshan urban complex ecosystem. Guangzhou: South China Agricultural University.

\section{Copyright Disclaimer}




\section{Macrothink}

Journal of Environment and Ecology

ISSN 2157-6092

Copyright for this article is retained by the author(s), with first publication rights granted to the journal.

This is an open-access article distributed under the terms and conditions of the Creative Commons Attribution license (http://creativecommons.org/licenses/by/3.0/). 